\title{
ANN-BASED DECISION MODEL FOR THE REUSE OF VACANT BUILDINGS IN URBAN AREAS
}

\author{
Yin-Hao HSU a,*, Yi-Kai JUAN a \\ a Department of Architecture, National Taiwan University of Science and Technology, No.43, Sec. 4, \\ Keelung Rd., Da-an Dist., Taipei 106, Taiwan
}

Received 22 September 2014; accepted 17 March 2015

\begin{abstract}
Because of global urbanization and sustainable development trends, reusing vacant buildings is a crucial strategy employed in urban development and management. Reusing and adjusting the future service values of unused buildings to extend building life cycles is a sustainable approach that benefits society, the economy, and the environment. However, repurposed spaces are easily re-discarded because a comprehensive system and operational plan for assessing the effects of building reuse remains unestablished. The research framework adopted in this study was based on the seven factors of the AdaptSTAR model; assessment criteria for building reuse were then created. In addition, 62 types of reused building cases in Taiwan were investigated and a decision model for reuse type prediction and business strategy was constructed on the basis of artificial neural networks. The results indicated that the proposed decision model yielded a reuse type accuracy of $89 \%$ and a business strategy accuracy of $78 \%$. This systematic approach can be adjusted according to local conditions and applied as an effective decision support tool.
\end{abstract}

KEYWORDS: Vacant building; Building reuse; Artificial neural network; Decision support system; Sustainable development

\section{INTRODUCTION}

In developed countries during the 1960s and 1970s, building reuse was the primary strategy and trend in urban development. Reusing buildings extends building life cycles and facilitates environmental sustainability, enhancing practical social and economic benefits (Yung, Chan 2012). In developed countries, $95-97 \%$ of buildings are existing building; reusing building structures, such as through refurbishments, infrastructure additions, and reconstruction, requires merely $50-75 \%$ of the time and $50-80 \%$ of the costs entailed in constructing anew (Highfield, Gorse 2009). Thus, applying approaches and business strategies that are based on cost conservation and sustainable building to reuse vacant buildings, extend building life cycles, and adjust the future service values of buildings is crucial for economic, social, and environmental building management (Douglas 2006; Langston et al. 2013; Roychansyah et al. 2005).

The developmental direction of the existing construction market is to convert various types of

* Corresponding author. E-mail: mou1021@gmail.com spaces and optimize vacant building reuse according to a sustainable development perspective (Tan et al. 2014; Davison et al. 2006). However, during space conversion, reuse, and development, problems are typically encountered; for example, some spaces cannot be adjusted to fulfill user requirements, plan and operation entities are inconsistent, and financial sources are unstable. These problems hinder building reuse projects from achieving expected results and operational objectives, resulting in low usage rates and the re-discarding of problematic reused spaces (Shipley et al. 2006). Moreover, use and development orientation types differ according to various economic, environmental, and social conditions; therefore, high variance rates exist in reuse approaches and management strategies (Langston, Shen 2007). Consequently, the practice actively adopted worldwide involves applying appropriate management strategies and approaches and ensuring reuse type and orientation (Langston et al. 2013).

In relevant building reuse studies, site investigation and survey methods have typically been 
adopted to explore the execution of building reuse projects. Some studies have conducted feasibility and potential evaluations by using approaches such as literature reviews, expert questionnaires, and interviews (Bullen, Love 2010; Conejos et al. 2013; Gann, Barlow 1996; Yung, Chan 2012). However, these studies have been primarily restricted to investigating one project type, not discussing reuse operational strategies. From the perspective of strategy management, building reuse types must be diverse, and business strategy selection directly influences the future efficacy of a reuse project. However, type positioning and management strategies have rarely been investigated.

The objective of this study was to construct a prediction model that could be applied to vacant building reuse type and management strategy. First, according to the AdaptSTAR model framework, a literature review and expert interviews were conducted to construct 30 evaluation criteria influencing building reuse decisions. Second, 62 vacant building cases involving various attributes and types in Taiwan were investigated and analyzed. An artificial neural network (ANN) was employed to construct the model; the evaluation criteria were used as input layers (X1-X30) and the reuse types and business strategies were applied as output layers ( $\mathrm{Y} 1$ and $\mathrm{Y} 2$ ). Among the records from the 62 cases, 9 test case records were analyzed, and the prediction results were used to examine system accuracy. Finally, model constructions and examinations were discussed and suggestions were offered.

\subsection{Vacant building reuse in Taiwan}

In Taiwan, building conservation began in 1970 . Although monuments were protected as historical sites, the conservation skills available were immature and the concepts were appropriate only for restoring and preserving historical buildings. In 1994, the government proposed a new policy for the development and cultural revival of communities by integrating districts and urban planning development. Historical spaces replete with local characteristics were targeted for conservation.

Because of a changing social structure and industry, numerous vacant buildings began to emerge in the late 1990s, affording opportunities to rethink the measures used to manage vacant buildings in urban areas. Therefore, the goal shifted from building conservation to more proactive approaches of building reuse. Building reuse promotion commenced in 1998, expanding to general public vacant buildings after 2000 .
After a decade of promoting, the Taipei City Government conducted a survey in 2013, determining that 203 public vacant buildings and 233 official dormitory buildings (total floor area: approximately 62,000 $\mathrm{m}^{2}$ ) remained unused (Department of Finance, Taipei City Government 2013). According to the research report of the National Policy Foundation (NPF 2008), there are three potentially controversial topics concerning building reuse in Taiwan: (1) There is only one reuse type, lacking diversity and the prospect of future use. (2) Intentions to reuse vacant buildings for new functions might be challenged by local building regulations and other legal requirements that might limit the reuse potential. (3) Management strategies for reuse, such as those related to financial sources and development orientation, are generally unclear. All of these disputes can contribute to the major problem that building reuse in Taiwan normally lacks comprehensive models for assessing management strategies and identifying diverse types of future reuse (Chen 2001; Fu 2001; Yang 2013). When demands for spaces of varying quality increase, inadequate reuse projects cause numerous reused spaces to be rediscarded. The government lacks effective strategies for repurposing vacant buildings that have been reused once.

Another trend in Taiwan that has accelerated the appearance of vacant buildings is the declining birth rate. In 2010, the birth rate in Taiwan was the lowest worldwide (Zhan, Lin 2013); the number of students has decreased yearly, and $21 \%$ of the country's classrooms (approximately 22,000 classrooms) are estimated to have been unoccupied for nearly three years. The government has projected that $30 \%$ of elementary and middle school spaces will be unoccupied by the end of 2028 because of the rapidly declining birth rate (Lu, Shi 2013).

Unlike building lifetimes in Western countries that can generally be sustained for more than 80 years, the average lifetime of buildings in Taiwan is only approximately 23.2 years (Chang 2002). Buildings in Taiwan might be demolished because of social considerations (e.g. requirement adjustments, functional changes) rather than because of durability concerns (e.g. physical damage, deterioration). Strategies and actions regarding reusing these vacant buildings to prolong building life cycles and increase future service values have become a major concern for the government, which aspires to vitalize sustainable urban environments.

Revitalizing the Songshan Cultural and Creative Park (SCCP) was among the most successful building reuse projects in Taiwan. The facility was 
originally a tobacco factory, constructed in 1937 during Japanese colonial occupation (SCCP 2013a). After Taiwan was relinquished to China in 1945, the Taiwan Provincial Monopoly Bureau gained control of the factory, renaming it the Songshan Tobacco Plant of the Taiwan Provincial Monopoly Bureau. In 1947, the plant was again renamed as the Songshan Tobacco Plant of the Taiwan Tobacco and Wine Bureau (Taipei Culture Foundation 2014). Production of rolled tobacco peaked in 1987, and more than 2,000 employees worked in the plant that once created tremendous economic value for the nation. However, because the markets were opened, tobacco demand declined, state-owned enterprises were privatized, and social structure changed; thus, the tobacco plant lost relevance and ceased to produce tobacco in 1998. In 2001, the Taipei City Government designated the obsolete plant as a historic site, converting it into the SCCP in 2010. In 2012, the SCCP was designated as the Creative Hub of Taipei to nurture creative talent and energy and provide historic, architectural venues for cultural and creative exhibitions and performances (SCCP 2013b). Figures 1(a) and 1(b) depict the transformation of the SCCP from 1950 to 2014, respectively.

a)

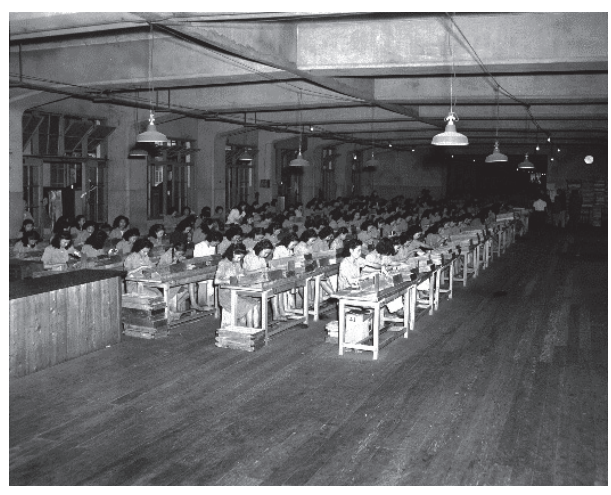

b)

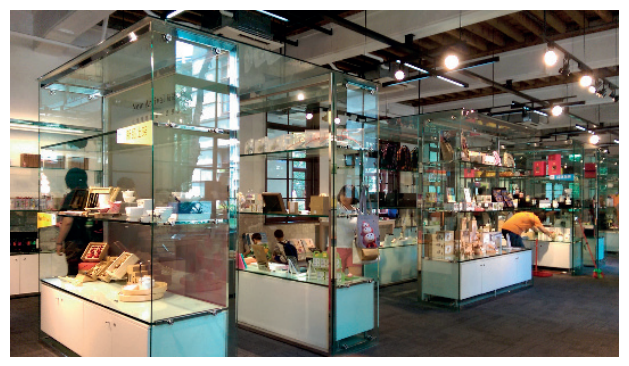

Fig. 1. (a) Female workers rolling tobacco in the factory. (b) Red Dot Award exhibition: communication design winners' selection

Official letters of authorization and the right for use have been obtained from the Central News Agency, R.O.C.

\section{OVERVIEW OF ADAPTIVE REUSE}

The number of vacant buildings in urban areas has increased following urban expansion and low birth rates. Building reuse is crucial for energy conservation and environmental sustainability because it minimizes demolition construction costs, vitalizes community development, and prevents urban sprawl (Bullen, Love 2011; Douglas 2006). Although new building materials feature superior energy conservation properties, new buildings account for less than $2 \%$ of the total number of buildings in developed countries; thus, the energy conservation effects of new buildings are considerably less than those exerted by reused buildings (Brown, Buranakarn 2003). Adaptive reuse is broadly defined as any building project or intervention designed to change building capacity, function, or performance by adjusting, reusing, or upgrading the building to fulfill new conditions or requirements (Douglas 2006); for example, converting factories into houses and military facilities into schools sustains the life cycle of buildings (Conejos et al. 2013; De Valence 2004; Douglas 2006).

The trend of reusing and adapting buildings extends the useful life of existing buildings and fosters the key concepts of building environment sustainability by reducing material, transportation, and energy consumption and pollution (Brown, Buranakarn 2003; Gallant, Blickle 2005). Thus, adaptive reuse is an effective strategy applied to various types of facilities worldwide, including prestigious buildings throughout the United States, Australia, and the Asia Pacific region (Department of Environment and Heritage 2004; Langston et al. 2008; United Nations Educational Scientific and Cultural Organization 2007).

In the past, decisions for building reuse were made according to experience and instinct (Highfield, Gorse 2009). Gradually, scholars have proposed research methods for evaluating building reuse to address the increasing number of vacant buildings (Langston, Shen 2007; Conejos et al. 2013). In most relevant studies, case studies, field surveys, and interviews have been conducted to assess building reuse. For example, Bullen (2007) designed a questionnaire with which to interview representatives of Australian enterprises and governmental departments, examining the assessment standards for vacant building sustainable development. In addition, Mine (2013) performed field research pertaining to the economic value and environmental benefits of reusing historical buildings in London and Amsterdam. Langston 
and Shen (2007) proposed a new reuse assessment model, the adaptive reuse potential (ARP) model, which can assess the physical, economic, functional, technological, social, legal, and political level of building conditions to calculate building life cycles. The AdaptSTAR model is another recent design-rating tool, created on the basis of the ARP model by Langston and a detailed analysis of 12 adaptive reuse projects in Australia; designers can adopt this model to make decisions that facilitate achieving optimal efficiency and useful life from creations. Examining the ARP and AdaptSTAR models revealed that both were highly correlated (Conejos et al. 2014). The seven crucial factors included in these two models can enable increased building life cycles and building sustainability.

Table 1. Factors affecting adaptive reuse

\begin{tabular}{|c|c|c|}
\hline Dimensions & Criteria & Source \\
\hline \multirow[t]{5}{*}{ Physical } & Structure & $\begin{array}{l}\text { Davison et al. (2006), Douglas (2006), Highfield } \\
\text { and Gorse (2009), Murtagh (1988) }\end{array}$ \\
\hline & Building age & Highfield and Gorse (2009), Horvath (2010) \\
\hline & Site area & Campbell (1996), Heath (2001) \\
\hline & Gross floor area & Campbell (1996), Heath (2001) \\
\hline & Building purpose before renovation & $\begin{array}{l}\text { Kincaid (2000, 2004), Rabun (2000), Vakili-Ardebili } \\
\text { (2007), Yudelson (2010) }\end{array}$ \\
\hline \multirow[t]{6}{*}{ Economic } & Urbanization level (population density) & Frey et al. (2008), Langston et al. (2008) \\
\hline & Accessibility of public transportation & Heath (2001), Prowler (2008) \\
\hline & Distance to downtown & Campbell (1996), Fealy (2006) \\
\hline & Primary consumer age & Stagl, O’Hara (2002), Williams (1996) \\
\hline & Job opportunity creation & Latham (2000) \\
\hline & Association level of relevant local assistant industry & Latham (2000) \\
\hline \multirow[t]{3}{*}{ Social } & Frequency and number of performances held & Jago and Shaw (1998), Jago et al. (2003) \\
\hline & $\begin{array}{l}\text { Density of valuable cultural resources in the } \\
\text { surrounding area }\end{array}$ & Bond and Charlemagne (2009) \\
\hline & Facility usage rate & Browne (2006) \\
\hline \multirow[t]{3}{*}{ Functional } & Cultural, artistic, and historical values of buildings & Bond and Charlemagne (2009), Nelson (2005) \\
\hline & Space adjustability & $\begin{array}{l}\text { Arge (2005), Bronson and Jester (1997), Horvath } \\
\text { (2010), Langston et al. (2008), Murtagh (1988), } \\
\text { Nelson (2005) }\end{array}$ \\
\hline & Spatial mobility, continuity, and openness & $\begin{array}{l}\text { Bronson and Jester (1997), Davison et al. (2006), } \\
\text { Horvath (2010), Murtagh (1988), Nelson (2005) }\end{array}$ \\
\hline \multirow[t]{3}{*}{ Technological } & Demand for construction equipment & $\begin{array}{l}\text { Heath (2001), Prowler (2008), Russell and Moffat } \\
\text { (2001) }\end{array}$ \\
\hline & Fireproof structural features & Davison et al. (2006), Douglas (2006), Heath (2001) \\
\hline & Building damage frequency & Douglas (2006), Prowler (2008) \\
\hline \multirow[t]{5}{*}{ Political } & Level of public sector cooperation & Pelling and High (2005), Trancik (1986) \\
\hline & Level of community involvement & \\
\hline & Learning opportunities provided & Trancik (1986) \\
\hline & Market profitability & \\
\hline & Financing capacity & \\
\hline \multirow[t]{5}{*}{ Legal } & Land use zoning & Browne (2006), Campbell (1996), Douglas (2006) \\
\hline & Building ownership & Heath (2001) \\
\hline & The presence of a major development project nearby & \\
\hline & Building coverage ratio & \\
\hline & Floor area ratio & \\
\hline
\end{tabular}

\section{CRITERIA FOR ADAPTIVE REUSE}

\subsection{Criteria establishment}

Evaluation criteria are crucial indicators of determining building adaptive reuse types and business strategies, for which this study endeavored to create a predictive model. The ARP model and AdaptSTAR model are two of the most frequently employed building reuse assessment models; their criteria, based on expert interviews and the literature, include physical, economic, functional, technological, social, legal, and political factors (Conejos et al. 2013), providing comprehensive standards for building adaptive reuse and sustainable building environments.

According to the ARP and AdaptSTAR models, Table 1 lists the integrated criteria used in the decision support system in this study and corresponding items from literature, expert interviews, and case studies. 


\subsection{Building types and business strategies for adaptive reuse}

Numerous studies have investigated cases of building reuse that involved repurposing existing buildings, such as converting offices into residences (Heath 2001), offices into apartments (Gann, Barlow 1996), or commercial buildings into spaces for other uses (Bullen 2007), or renovating buildings to create the same building type operating in a different operation mode. According to the Department of Environment and Heritage (2004: 3), "Adaptive reuse is a process that changes a disused or ineffective item into a new item that can be used for a different purpose". Adaptive reuse can also be described as a "process by which to ameliorate the financial, environmental, and social performance of buildings" (Bullen 2007; Langston, Shen 2007).

This study investigated 62 successful building reuse projects in Northern Taiwan and categorized them into six building types: business facilities (9 cases), educational facilities (9 cases), office facilities (11 cases), residences (14 cases), art exhibition spaces (12 cases), and art villages ( 7 cases). These six building types account for $95 \%$ of the reused buildings in Taiwan. The collection and selection of these building reuse projects involved three stages. First, according to field research and a literature review, 82 projects were initially selected and subsequently examined using three criteria: (1) The building could be continually oc- cupied without structural safety concerns; (2) use function of the building could be adjusted to extend the service life of the building; and (3) the reuse project could enhance its economic viability (Cheng, Fu 2010). Regarding economic viability, all of the selected projects must have operated for more than three years after reuse and currently have stable profit. At this stage, 73 projects were selected. Second, 90 citizens and end-users who regularly visited these reused buildings were administered a questionnaire survey. Four projects were eliminated according to the low satisfaction of the respondents. Finally, six experts participated in a panel discussion on the appropriateness of project selection. After consideration of project scale, operating conditions, and social impact, another seven projects were removed and a final total of 62 projects was obtained.

In addition, this study examined three major types of business strategies employed in these projects: government-run businesses (GRB), privately managed public establishments (PMPE), and privately owned businesses (POB) (Table 2). Among the three types, the primary mode adopted by the public sector to operate building reuse is the PMPE, which involves governmental supervision of human and management resources from the private sector to facilitate operational efficiency, reduce operating costs, and enhance the quality and functionality of public services. The PMPE includes four operating types: operate-transfer (OT),

Table 2. Business strategy

\begin{tabular}{|c|c|c|}
\hline \multicolumn{2}{|l|}{ Type } & Definition \\
\hline \multicolumn{2}{|c|}{ Government-run businesses (GRB) } & $\begin{array}{l}\text { Businesses established, invested, or reinvested using capital from the govern- } \\
\text { ment. All or the majority shares of the enterprises are directly owned by the gov- } \\
\text { ernment and are fully managed by the government. }\end{array}$ \\
\hline \multirow[t]{4}{*}{ PMPE } & Operation-transfer (OT) & $\begin{array}{l}\text { Once the construction of a government-funded building is completed, the opera- } \\
\text { tional rights are entrusted to a private institution until the operational period } \\
\text { expires, after which the government reassumes operational rights. }\end{array}$ \\
\hline & $\begin{array}{l}\text { Rehabilitate-operation- } \\
\text { transfer (ROT) }\end{array}$ & $\begin{array}{l}\text { A private institution is commissioned by the government, or leases existing facili- } \\
\text { ties from the government, for operation after expansion and renovation. After the } \\
\text { operational period expires, the government reassumes operational rights. }\end{array}$ \\
\hline & $\begin{array}{l}\text { Build-operate-transfer } \\
\text { (BOT) }\end{array}$ & $\begin{array}{l}\text { The government provides concession to a certain entity from the private sector } \\
\text { and allows it to invest and build a certain public construction project. The govern- } \\
\text { ment protects the market exclusivity of the public construction during a certain } \\
\text { period for it to make profit. The private sector entity must unconditionally return } \\
\text { the public construction to the government once the contract expires. A private } \\
\text { institution invests in and operates a public construction and eventually surren- } \\
\text { ders ownership of the public construction to the government and loses operational } \\
\text { rights once the operational period expires. }\end{array}$ \\
\hline & $\begin{array}{l}\text { Lease-renovate-operate- } \\
\text { transfer (LROT) }\end{array}$ & $\begin{array}{l}\text { A private sector entity leases an old public construction owned by a public sector } \\
\text { entity. The public construction is then renovated and operated by a licensee from } \\
\text { the private sector entity. }\end{array}$ \\
\hline \multicolumn{2}{|c|}{ Privately owned businesses (POB) } & $\begin{array}{l}\text { A nongovernmental private sector entity establishes and invests in a business. All } \\
\text { or the majority of the shares of the enterprise are directly owned by the private } \\
\text { sector entity, and it possesses direct management rights. }\end{array}$ \\
\hline
\end{tabular}


rehabilitate-operate-transfer (ROT), build-operate-transfer, and lease-renovate-operate-transfer (LROT). In this study, the relationships between business strategy modes and types of reuse were also investigated.

\section{RESEARCH METHOD}

\subsection{Artificial neural network}

Large amounts of neuronal connections occur in the human brain, of which the ANN is a simplified model. The ANN, which imitates the operation of the biological neuronal network by connecting and storing learned knowledge in neurons (Giudici 2003), is an information processing technique that was developed according to brain and neuronal system studies. In the past few years, the ANN has been employed widely and the established system models based on ANN approaches can be applied in prediction and decision-making problems. The ANN is among the greatest parameterized models and has attracted the attention of researchers from every domain (Hand et al. 2001).

Highly complex neuronal networks replace systematic mathematical models in the ANN, eliminating the need to comprehend such models. When information is incomplete, particularly in the decision-related content of this research, the relationships between the complex nonlinear input and output values can still be obtained (Ling, Liu 2004). Compared with traditional statistical skills and inductive learning, the ANN can be applied to construct nonlinear models, produce accurate output values, and even accept input values of different types or unknown variables. In addition, the ANN is extremely reproducible and accurate.

The back-propagation (BP) neural network algorithm, one of the most widely applied ANN models, is basically a multilayer feedforward network (typically comprising one input, one hidden, and one output layer) that searches for the minimum of the error function in weight space using the method of gradient decent. BP can be used to learn and store numerous mapping relations of an input-output model to determine a function that most accurately maps a set of inputs to the correct output. Moreover, disclosing in advance the mathematical equation that describes these mapping relations is unnecessary (Rojas 1996). Because of its convenience, efficiency, and potential to improve the performance of neural networks and enhance the model prediction accuracy (Kumar et al. 2013; Li et al. 2012), BP was selected as the major method through which to operate the ANN in this study.

\subsection{Operation of the artificial neural network}

In this study, the aforementioned impact criteria were utilized as the input layer (X1-X30), and adaptive reuse type and business strategy were used as the output layer (Y1 and Y2) in an ANN (Table 3) to examine whether the reuse indicator (input) was a key factor influencing the reuse types and business strategies related to vacant buildings. These factors were derived from literature reviews and case studies. Table 3 details each variable (according to Table 1) and defines its corresponding assessment scale. The rules of determining the assessment scale were developed according to Taiwan reuse regulations, practices, and local conditions. On the basis of these rules, the assessments can be objectively determined by the research team and experts. For example, regarding the variable "X7: Accessibility of public transportation," White and McDaniel (1999) proposed the concept of a walkable distance (400$600 \mathrm{~m}$ ) in urban areas according to the theory of market economics; the shorter the distance, the more feasible the project is. In view of the urban scale, density, and public transportation conditions in Northern Taiwan, this variable was defined as a "walkable distance from the site to the nearest public transportation system, including train stations, bus stops, and mass rapid transit stations." Five scales were further determined: Scale 1: a distance exceeding 1,600 m (not accessible); Scale 2: a distance between 1,200 $\mathrm{m}$ and 1,599 m; Scale 3: a distance between $800 \mathrm{~m}$ and $1,199 \mathrm{~m}$; Scale 4: a distance between $401 \mathrm{~m}$ and $799 \mathrm{~m}$; and Scale 5: a distance less than $400 \mathrm{~m}$ (highly accessible).

The ANN model can efficiently estimate building type and business strategy by learning from the numerical data and complex nonlinear relationships among the investigated building cases. The algorithm consists of various input layers, hidden layers, and output layers operating in parallel. The initial outputs obtained using an ANN-based decision model were applied to derive the prediction results, including suggestions for appropriate building type and business strategy. The network architecture included 30 input layers, five hidden layers, and two output layers; Figure 2 depicts a simplified ANN model. Neuralyst software was used to design and train the ANN model. To prevent overtraining, the model began with three neurons in the hidden layers and was optimized with five neurons. Among the 62 cases, 53 cases were randomly designed, and nine test cases were randomly selected by the ANN system to validate the 
model's predictive performance. Figure 3 depicts the training curve of the ANN model after 11,072 epochs. Network parameter settings, such as the learning rate (0.6), momentum (0.9), training tolerance $(0.1)$, and testing tolerance $(0.3)$, were fur- ther defined. The SYMBOL mode was selected for the ANN operation and the symbol list included six types and six strategies. In this situation, the root mean square (RMS) error of the training cases achieved 0.0029 .

Table 3. Interpretations of building adaptive reuse factors

\begin{tabular}{|c|c|c|c|}
\hline $\begin{array}{l}\text { Dimen- } \\
\text { sions }\end{array}$ & $\begin{array}{l}\text { Vari- } \\
\text { ables }\end{array}$ & Explanatory variables & Definition \\
\hline \multirow[t]{5}{*}{ Physical } & $\mathrm{X} 1$ & Structure type & $\begin{array}{l}1=\text { wooden structure } 2=\text { brick structure; } \\
3=\text { reinforced brick structure } 4=\text { reinforced } \\
\text { concrete } 5=\text { steel structure }\end{array}$ \\
\hline & $\mathrm{X} 2$ & Building age & Years; $1=1-20 ; 2=21-40 ; 3=41-60 ; 4 \geq 60$ \\
\hline & $\mathrm{X} 3$ & Site area & $\mathrm{m}^{2}$ \\
\hline & $\mathrm{X} 4$ & Gross floor area & $\mathrm{m}^{2}$ \\
\hline & $\mathrm{X} 5$ & $\begin{array}{l}\text { Building purpose before } \\
\text { renovation }\end{array}$ & $\begin{array}{l}1=\text { residential } ; 2=\text { warehouse } ;=\text { retail } ; 4= \\
\text { educational institution; } 5=\text { others; } 6=\text { hotel; } \\
7=\text { manufacturing; } 8=\text { office; } 9=\text { health care }\end{array}$ \\
\hline \multirow[t]{6}{*}{ Economic } & $\mathrm{X} 6$ & $\begin{array}{l}\text { Urbanization level (popula- } \\
\text { tion density) }\end{array}$ & $\begin{array}{l}\text { Population }\left(\text { people } / \mathrm{km}^{2}\right) ; 1 \leq 500 ; 2=501- \\
1,000 ; 3=1,001-2,000 ; 4=2,001-4,000 ; 5= \\
4,001-8,000 ; 6 \geq 8,001\end{array}$ \\
\hline & $\mathrm{X} 7$ & $\begin{array}{l}\text { Accessibility of public trans- } \\
\text { portation }\end{array}$ & $\begin{array}{l}\mathrm{m} ; 1 \geq 1600 \text { (not accessible) } 2=1200-1599 \\
3=800-1199 ; 4=401-799 ; 5 \leq 400 \text { (highly } \\
\text { accessible) }\end{array}$ \\
\hline & $\mathrm{X} 8$ & Primary consumer age & $\begin{array}{l}\text { Age } 0=1-14 ; 2=15-29 ; 3=30-44 ; 4= \\
45-64 ; 5 \geq 65\end{array}$ \\
\hline & $\mathrm{X} 9$ & Distance to downtown & $\mathrm{Km} ; 1=0-5 ; 2=6-10 ; 3=11-15 ; 4 \geq 16$ \\
\hline & $\mathrm{X} 10$ & Job opportunity creation & $1=0 ; 2=1-5 ; 3=6-10 ; 4=11-20 ; 5 \geq 21$ \\
\hline & $\mathrm{X} 11$ & $\begin{array}{l}\text { Association level of relevant } \\
\text { local assistant industry }\end{array}$ & $\begin{array}{l}\text { Number of relevant industries involvement; } \\
1=0 ; 2=1 ; 3=2 ; 4=3 ; 5 \geq 4\end{array}$ \\
\hline \multirow[t]{3}{*}{ Social } & $\mathrm{X} 12$ & $\begin{array}{l}\text { Frequency and number of } \\
\text { performances held }\end{array}$ & $\begin{array}{l}\text { Times/year; } 1=0 ; 2 \leq 10 ; 3=11-20 ; 4= \\
21-30 ; 5 \geq 31\end{array}$ \\
\hline & $\mathrm{X} 13$ & $\begin{array}{l}\text { Density of valuable cultural } \\
\text { resources in the surround- } \\
\text { ing area }\end{array}$ & $\begin{array}{l}\text { Density (number of cultural facilities } / \mathrm{km}^{2} \text { ); } \\
1=0 ; 2=1-3 ; 3=4-6 ; 4=7-10 ; 5 \geq 11\end{array}$ \\
\hline & $\mathrm{X} 14$ & Facility usage rate & $\begin{array}{l}\text { Estimated visitors/users (\%: real/estimated); } \\
1 \leq 20 \% ; 2=21-40 \% ; 3=41-60 \% ; 4=61- \\
80 \% ; 5=81-100 \%\end{array}$ \\
\hline
\end{tabular}

Source

Highfield and Gorse (2009)

Highfield and Gorse (2009), Horvath (2010)

Campbell (1996), Heath (2001)

Campbell (1996), Heath (2001)

Ling and Liu (2004)

Langston et al. (2008)

White and McDaniel (1999)

Stagl and O'Hara (2002)

Fealy (2006)

Latham (2000)

Latham (2000)

Jago and Shaw (1998), Jago et al. (2003)

Bond and Charlemagne (2009), Cohen (2002), Oliver (1997)

Browne (2006), Stevenson and Hojati (2007)

Func- X15 Cultural, artistic, and histional torical values of buildings

5 classes; 1 = general buildings; $2=$ historical buildings; $3=3^{\text {rd }}$ class monuments; $4=2^{\text {nd }}$ class monuments; $5=1^{\text {st }}$ class monuments

X16 Space adjustability

Scale $1-5 ; 1=$ R.C. partition; $2=$ brick partition; $3=$ wood partition; $4=$ light steel frame partition; $5=$ no partition

Bond and Charlemagne (2009), Ministry of Culture (2011)

Kim and Juan (2014), Lee and Brand (2005), O’Neill (1994)

X17 Spatial mobility, continuity, Ratio of open space (\%); $1 \leq 20 \% ; 2=21-30 \%$; and openness $\quad 3=31-40 \% ; 4=41-50 \% ; 5 \geq 51 \%$

Horvath (2010), Fisher-

Gewirtzman and Wagner (2003), Department of Urban Development (DUD) (2011)

\begin{tabular}{|c|c|c|c|}
\hline \multirow[t]{3}{*}{$\begin{array}{l}\text { Techno- } \\
\text { logical }\end{array}$} & $\mathrm{X} 18$ & $\begin{array}{l}\text { Demand for construction } \\
\text { equipment }\end{array}$ & $\begin{array}{l}\text { Replacement ratio }(\%) ; 1=0 \% ; 2 \leq 25 \% ; 3= \\
26-50 \% ; 4=51-75 \% ; 5 \geq 76 \%\end{array}$ \\
\hline & $\mathrm{X} 19$ & $\begin{array}{l}\text { Fireproof structural fea- } \\
\text { tures }\end{array}$ & $\begin{array}{l}\text { Scale } 1-5 ; 1=\text { no fireproofing; } 2=0.5 \text { hour } \\
\text { fire rating; } 3=1 \text { hour fire rating; } 4=2 \text { hours } \\
\text { fire rating; } 5=3 \text { hours fire rating }\end{array}$ \\
\hline & $\mathrm{X} 20$ & Building damage condition & $\begin{array}{l}\text { Ratio of destroyed parts (\%); } 1 \geq 80 \% \text { (almost } \\
\text { collapse); } 2=60-79 \% \text { (serious); } 3=40-59 \% \\
\text { (moderate); } 4=21-39 \% \text { (some); } 5 \leq 20 \% \\
\text { (slight) }\end{array}$ \\
\hline
\end{tabular}

Prowler (2008), Ling and Liu (2004)

Douglas (2006), Construction and Planning Agency (CPA) (2014b)

Prowler (2008), CPA (2008) (moderate); $4=21-39 \%$ (some); $5 \leq 20 \%$ (slight)

(Continued) 


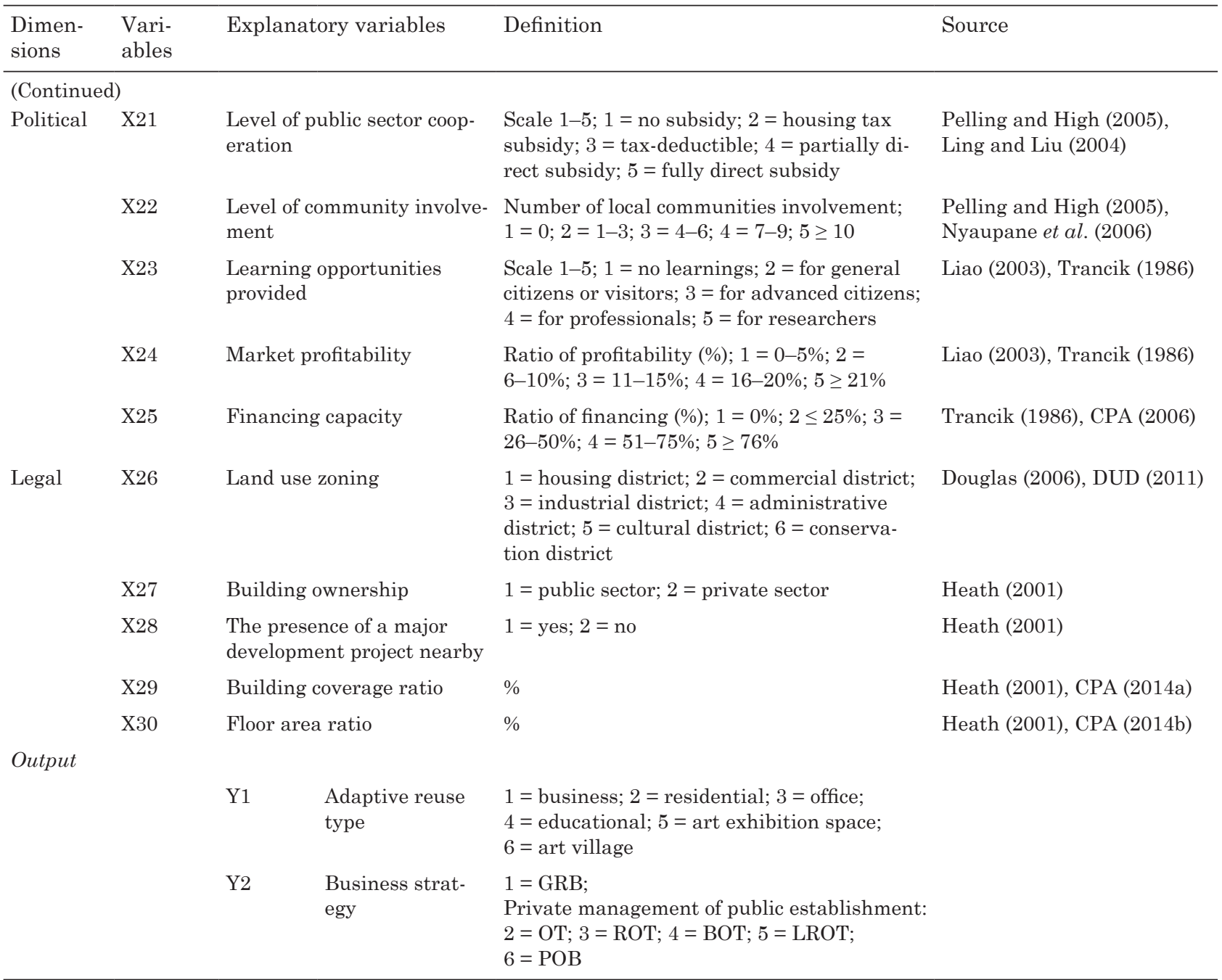

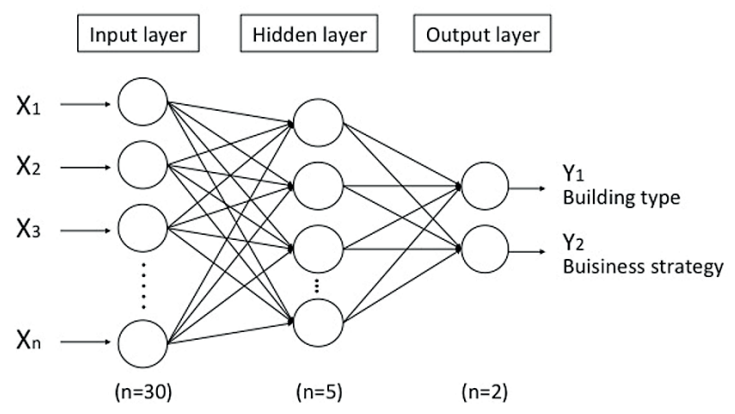

Fig. 2. Simplified feedforward neural network architecture

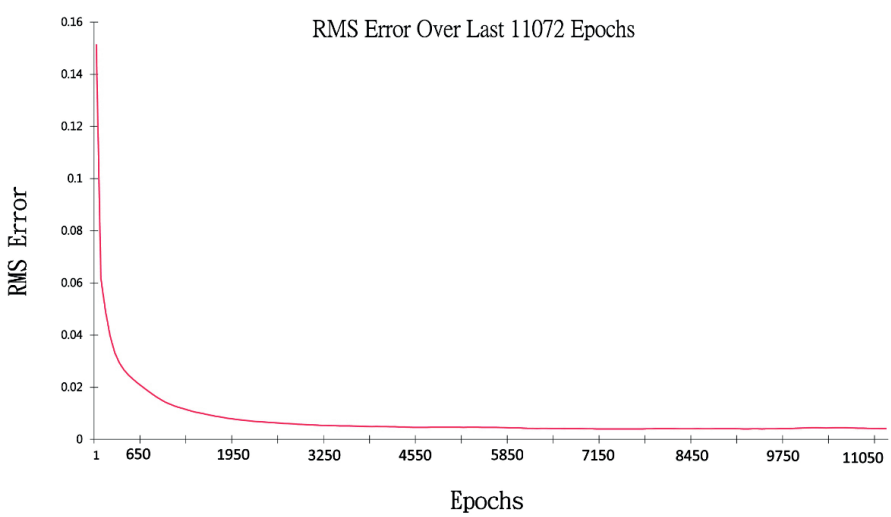

Fig. 3. The RMS error convergence curve 


\section{RESULTS AND DISCUSSION}

After reiterated tests from 62 cases of effective building reuse, the following sampling size (53 cases for training cases and 9 cases for test cases) was determined to achieve high prediction accuracy of the ANN model. The model analyses were conducted by randomly selecting types of test cases. The cases included six reuse types (Y1) and six business strategies (Y2). The accuracy and applicability of the ANN models were examined by comparing reuse types, the actual business strategy values, and the model prediction results, on the basis of Equation (1).

According to the results in Table 4, the ANN correctly classified eight of the nine building type selections (accuracy rate, 89\%) and seven of the nine business strategies (accuracy rate, 78\%; prediction RMS error, 0.099; one building type case and two business strategy cases were predicted incorrectly).

Prediction accuracy (PA):

$$
P A=1-\frac{\text { number of failures }}{\mathrm{n}} \times 100 \% \text {. }
$$

Based on prediction results and analyses of reuse projects, the following is a discussion of the findings:

- Nine projects were reused as business facilities, characterized by the highest assessment rating in the economic dimension. For example, seven projects were located near the downtown area (X9: less than $5 \mathrm{~km}$ ); public transportation (X7) was highly accessible; and primary consumer age (X8) was relatively young ( $78 \%$ were younger than 29 years). These results illustrated that business activities were highly related to urban transportation and populations, and the features and fashionable pop-culture connotations of buildings reused as business facilities were attractive to the young generation. Some variables, such as frequency and number of performances held (X12), density of valuable cultural resources in the surrounding area (X13), the facility usage rate (X14), and market profitability (X24), also received high ratings. The results revealed that a successful reuse project for business purposes might be strongly influenced by not only economic concerns, but also social and political characteristics that might attract crowds, and therefore stimulate the local business growth.

- Fourteen projects were reused as residences. These projects generally had a higher assessment in physical and technological dimensions, such as stronger building structures (X1), newer buildings (X2), higher demand for construction equipment (X18), more effective fireproof structural features (X19), and more sound building conditions (X20). The results indicated that in buildings reused as residence, more attention was paid to the quality of the current conditions. All projects adopted the POB as their business strategies, possibly because the building ownership of these projects was from the private sector; some of the new owners were more willing to renovate these aged but distinctive buildings for new accommodations (i.e. B\&Bs, hotels, and vacation rentals) that can create commercial opportunities. This assumption can be verified by the result of the assessment of the market profitability (X24), showing that the average rating has reached 4.4 with an average $23 \%$ profitability.

- Eleven projects were reused as offices. These projects received high assessments in functional and economic dimensions, such as space adjustability (X16); spatial mobility,

Table 4. ANN model prediction results

\begin{tabular}{|c|c|c|c|c|c|}
\hline \multicolumn{2}{|c|}{ Actual value (target) } & \multicolumn{2}{|c|}{ ANN predictive value (output) } & \multicolumn{2}{|l|}{ Outcome } \\
\hline Building type & Business strategy & Building type & Business strategy & $\mathrm{Y} 1$ & Y2 \\
\hline Art village & OT & Art village & OT & Success & Success \\
\hline Business & POB & Business & POB & Success & Success \\
\hline Business & BOT & Business & $\mathrm{BOT}$ & Success & Success \\
\hline Office & POB & Educational & LROT & Fail & Fail \\
\hline Residential & POB & Residential & РOB & Success & Success \\
\hline Office & BOT & Office & GRB & Success & Fail \\
\hline $\begin{array}{l}\text { Art exhibition } \\
\text { space }\end{array}$ & $\mathrm{OT}$ & $\begin{array}{l}\text { Art exhibition } \\
\text { space }\end{array}$ & $\mathrm{OT}$ & Success & Success \\
\hline Residential & POB & Residential & POB & Success & Success \\
\hline Art village & ROT & Art village & ROT & Success & Success \\
\hline \multicolumn{4}{|c|}{ Prediction accuracy (\%) } & $89 \%$ & $78 \%$ \\
\hline
\end{tabular}


continuity, and openness (X17); accessibility of public transportation (X7); and job opportunity creation (X10). Because client requirements are complicated and occupation is irregular, providing flexible space for office use is necessary. However, for some projects, the locations were not near downtown, possibly because high housing prices and rent downtown has forced some office facilities to relocate to the suburbs. In this case, reused buildings with convenient access to public transportation were more likely to become office facilities.

- Nine projects were reused as educational facilities. The political and functional dimensions received high assessment; in particular, the level of public sector cooperation (X21) achieved the highest assessment rating, possibly because all of these properties belonged to the government, which tended to reuse them for nonprofit facilities, such as educational facilities. This result verifies that the major business strategies for these projects were GRB (78\%) and LROT (22\%). However stable and long-term financial support from the government is critical to the success of a reuse project. Once the subsidy from the public sector is terminated, the operation of these projects might be extremely affected, and the buildings are prone to becoming re-vacated.

- Twelve projects were reused as art exhibition spaces. Some characteristics can be observed from these projects: a building age exceeding 50 years (X2); a high density of valuable cultural resources in the surrounding area (X13); a facility usage rate (X14); great cultural, artistic, and historical building value (X15), and enhanced spatial mobility, continuity, and openness (X17). In addition, the level of community involvement (X22) was also significant, indicating that encouraging local residents to participate in co-managing art exhibition spaces was meaningful. The synergy of these characteristics enable integrating the surrounding environment, people, and facilities to develop spaces appropriate for art exhibitions.

- Seven projects were reused as art villages. These projects were usually large-scale with huge site areas (X3) and gross floor areas (X4). The distances from the sites to the downtown area were relatively far (X5). The literature and interviews showed that this kind of project was spontaneously conducted by nongovernment organizations, such as artist societies, in the early phase of the building reuse movement. Because the government owned most of these buildings and in view of the operation and management efficiency, as well as the style and autonomy of the village they expected to establish, the business strategies adopted for these projects were PMPE (four cases for ROT and three cases for OT). The above-mentioned SCCP was a successful example of this project type. However, the potential risk of operating these projects included establishing development strategies for the villages and managing conflict of interests from different business parties during operation.

\section{CONCLUSIONS}

This study developed a decision support model that can enable project managers to determine adaptive building reuse and business strategies and create highly efficient sustainable buildings. The model was established in two steps. The first step involved determining reuse assessment factors. A literature review was conducted and discussions of successful building reuse cases in Taiwan were analyzed and investigated. In addition, the seven factors from the building reuse design assessment models, the AdaptSTAR and ARP models, were integrated to construct 30 assessment factors that influence building reuse type and business strategies. The second step pertained to constructing the ANN prediction model. After the 62 effective building reuse cases in Taiwan were surveyed, 53 training cases were input into the ANN for learning and nine cases were randomly selected to validate the accuracy of the ANN system. The results indicated that the accuracy of the ANN model in predicting reuse and business strategy type was $89 \%$ and $78 \%$, respectively. In addition, the predictive performance of the model indicated that the main factors or key determinants were correctly identified in the AdaptSTAR model framework and can be used to effectively predict appropriate building type and business strategies.

For vacant buildings in urban areas that remain a concern, the proposed model can effectively provide decision makers with an optimal prediction method for determining building reuse types and business strategies in the initial stage of urban development and management. The model can greatly improve operation efficiency, the value of reuse, and cooperation among various parties who are interested in reuse projects. Most importantly, 
precise reuse processes and decision-making can ensure the success of a project that can benefit society, the economy, and the environment through sustainability.

The proposed model and prediction results were only tested in Northern Taiwan. However, each city has unique characteristics, challenges, and opportunities. In future studies, when considering the reuse of various buildings, the influential factor (X), development type (Y1), and business strategy (Y2) must be adjusted according to the development area conditions. The aspects and feasibility conditions of building reuse (i.e., developmental and operational costs and risk prediction) must be comprehensively investigated to determine all possible influencing factors and developmental limitations. In addition, more successful reuse cases should be surveyed and analyzed to enhance the objectiveness and accuracy of decision support systems.

\section{REFERENCES}

Arge, K. 2005. Adaptable office buildings: theory and practice, Facilities 23(3/4): 119-127. http://dx.doi. org/10.1108/02632770510578494

Bond, S.; Charlemagne, D. W. 2009. Built cultural heritage and sustainability-the role of value based decisions, in EU Sustainable Energy Week, 9-13 February 2009, Brussels, Belgium.

Bronson, S. D.; Jester, T. C. 1997. Conserving the built heritage of the modern era: recent developments and ongoing challenges, APT Bulletin 28(4): 4-12. http:// dx.doi.org/10.2307/1504588

Brown, M. T.; Buranakarn, V. 2003. Emergy indices and ratios for sustainable material cycles and recycle options, Resources, Conservation and Recycling 38(1): 1-22. http://dx.doi.org/10.1016/S0921-3449(02)00093-9

Browne, L. A. 2006. Regenerate: reusing a landmark building to economically bolster urban revitalization. Doctoral dissertation, Cincinnati, OH: University of Cincinnati.

Bullen, P. A. 2007. Adaptive reuse and sustainability of commercial buildings, Facilities 25(1/2): 20-31. http://dx.doi.org/10.1108/02632770710716911

Bullen, P. A.; Love, P. E. 2010. The rhetoric of adaptive reuse or reality of demolition: views from the field, Cities 27(4): 215-224. http://dx.doi.org/10.1016/j.cities.2009.12.005

Bullen, P.; Love, P. 2011. A new future for the past: a model for adaptive reuse decision-making, Built Environment Project and Asset Management 1(1): 32-44. http://dx.doi.org/10.1108/20441241111143768

Campbell, J. 1996. Is your building a candidate for adaptive reuse?: C-class office buildings and unused industrial space can find new life through creative renovation and reuse, Journal of Property Management 61: 26-29.
Chang, Y. S. 2002. Life cycle assessment on the reduction of carbon dioxide emission of buildings. Doctoral dissertation, Tainan, Taiwan: National Cheng Kung University.

Cheng, M. T.; Fu, C. C. 2010. Research of space cluster of cultural and creative industry by the reuse of historic buildings: a case study of the Taiwan's cultural creative quarters, in $8^{\text {th }}$ Annual Hawaii International Conference on Arts and Humanities, 13-16 January 2010, Hawaii, USA. Digital Proceedings.

Conejos, S.; Langston, C.; Smith, J. 2013. AdaptSTAR model: a climate-friendly strategy to promote built environment sustainability, Habitat International 37: 95-103. http://dx.doi.org/10.1016/j.habitatint.2011.12.003

Conejos, S.; Langston, C.; Smith, J. 2014. Designing for better building adaptability: a comparison of adaptSTAR and ARP models, Habitat International 41: 8591. http://dx.doi.org/10.1016/j.habitatint.2013.07.002

Chen, C. H. 2001. Practical experience and observation on promotion of the Redundant Spaces in Taiwan, in International Symposium on Reuse of the Redundant and Neglected Historic Spaces and Buildings in Taiwan, Tainan, Taiwan. Tainan: Council for Cultural Affairs, 1-4.1-1-4.7.

Cohen, E. 2002. Authenticity, equity and sustainability in tourism, Journal of Sustainable Tourism 10(4): 267276. http://dx.doi.org/10.1080/09669580208667167

Construction and Planning Agency (CPA). 2006. The operation essentials of finance project for urban renewal [online]. Construction and Planning Agency, Ministry of the Interior, Republic of China. Available at: http://www.cpami.gov.tw/chinese/index. php?option $=$ com_content\&view $=$ article\&id=10317\&I temid=57 [accessed 31 January 2015]

Construction and Planning Agency (CPA). 2008. Postdisaster building appraisal standards and requirements [online]. Construction and Planning Agency, Ministry of the Interior, Republic of China. Available at: http://www.cpami.gov.tw/chinese/index. php?option $=$ com_content\&view $=$ article\&id=10503\&I temid=57 [accessed 31 January 2015]

Construction and Planning Agency (CPA). 2014a. Taiwan province's enforcement rules of urban planning law [online]. Construction and Planning Agency, Ministry of the Interior, Republic of China. Available at: http://www.cpami.gov.tw/chinese/index. php?option=com_content\&view=article\&id=10712\&I temid=57 [accessed 31 January 2015]

Construction and Planning Agency (CPA). 2014b. Building technical regulations [online]. Construction and Planning Agency, Ministry of the Interior, Republic of China. Available at: http://w3.cpami.gov.tw/law/ law/lawe-2/b-rule.htm [accessed 31 January 2015]

Department of Urban Development (DUD). 2011. Taipei City land zoning regulations [online]. Department of Urban Development, Taipei City Government, Taipei. Available at: http://www.planning.taipei.gov.tw/ pages/detail.aspx? Node $=46 \&$ Page $=2102 \&$ Index $=5$ [accessed 31 January 2015]

Davison, N.; Gibb, A. G.; Austin, S. A.; Goodier, C. I.; Wagner, P. 2006. The multispace adaptable building concept and its extension into mass customisation, in 
Scheublin, F.; Pronk, A. (Eds.). Proceedings of the Joint CIB, IASS International Conference on Adaptability in Design and Construction, 3-5 July 2006, Eindhoven University of Technology, Eindhoven. Eindhoven: Eindhoven University of Technology, 12.7-12.13.

De Valence, G. 2004. The construction sector system approach. CIB Publication No. 293. CIB, Rotterdam.

Department of Environment and Heritage. 2004. Adaptive reuse: preserving our past, building our future [online]. ACT: Department of Environment and Heritage, Commonwealth of Australia. Available at: http://www.environment.gov.au/system/files/ resources/3845f27a-ad2c-4d40-8827-18c643c7adcd/ files/adaptive-reuse.pdf [accessed 25 January 2015]

Department of Finance, Taipei City Government. 2013. The municipal government has been actively reviewing the utilization strategies for idle dormitories, and the feasibility of leasing out idle buildings as public housing [online]. Department of Finance, Taipei City Government, Taipei. Available at: http://www.dof.taipei.gov.tw/ct.asp?xitem $=69887067 \&$ CtNode $=40183 \&$ $\mathrm{mp}=103007$ [accessed 8 August 2014]

Douglas, J. 2006. Building adaptation. London: Butterworth-Heinemann.

Fealy, J. W. 2006. Adaptive-reuse for multi-use facilities in an urban context: making the city home again. Doctoral dissertation, Cincinnati, OH: University of Cincinnati.

Frey, P.; Anderson, P.; Andrews, M.; Wolf, C. 2008. Building reuse: finding a place on American climate policy agendas. National Trust for Historic Preservation, Washington, DC.

Fisher-Gewirtzman, D.; Wagner, I. A. 2003. Spatial openness as a practical metric for evaluating built-up environments, Environment and Planning B 30(1): 37-50. http://dx.doi.org/10.1068/b12861

Fu, C. C. 2001. A theoretical structure on reuse of the redundant spaces in Taiwan, in International Symposium on Reuse of the Redundant and Neglected Historic Spaces and Buildings in Taiwan, Tainan, Taiwan. Tainan: Council for Cultural Affairs, 1-1.1-1-1.9.

Gallant, B. T.; Blickle, F. W. 2005. The building decommissioning assessment: a new six-step process to manage redevelopment of brownfields with major structures, Environmental Practice 7(2): 97-107. http://dx.doi.org/10.1017/S1466046605050131

Gann, D. M.; Barlow, J. 1996. Flexibility in building use: the technical feasibility of converting redundant offices into flats, Construction Management and Economics 14(1): 55-66. http://dx.doi. org/10.1080/01446199600000007

Giudici, P. 2003. Applied data mining: statistical methods for business and industry. New York: Wiley.

Hand, D.; Mannila, H.; Smyth, P. 2001. Principles of data mining. Cambridge, MA: The MIT Press.

Heath, T. 2001. Adaptive re-use of offices for residential use: the experiences of London and Toronto, Cities 18(3): 173-184. http://dx.doi.org/10.1016/S02642751(01)00009-9

Highfield, D.; Gorse, C. 2009. Refurbishment and upgrading of buildings. London: Taylor \& Francis.
Horvath, T. 2010. Necessity of modernization of modern buildings, in The 2010 CIB World Congress - Building a Better World, 10-13 May 2010, Salford Quays, United Kingdom, 204-216.

Jago, L. K.; Shaw, R. N. 1998. Special events: a conceptual and definitional framework, Festival Management and Event Tourism 5(1-2): 1-2. http://dx.doi. org/10.3727/106527098792186775

Jago, L.; Chalip, L.; Brown, G.; Mules, T.; Ali, S. 2003. Building events into destination branding: insights from experts, Event Management 8(1): 3-14. http:// dx.doi.org/10.3727/152599503108751658

Kim, J. H.; Juan, Y. K. 2014. Artificial neural network based decision model for alternative workplaces, Journal of Asian Architecture and Building Engineering 13(1): 85-91. http://dx.doi.org/10.3130/ jaabe.13.85

Kincaid, D. 2000. Adaptability potentials for buildings and infrastructure in sustainable cities, Facilities 18(3/4): 155-161. http://dx.doi. org/10.1108/02632770010315724

Kincaid, D. 2004. Adapting buildings for changing uses: guidelines for change of use refurbishment. London: Spon Press.

Kumar, R.; Aggarwal, R. K.; Sharma, J. D. 2013. Energy analysis of a building using artificial neural network: a review, Energy and Buildings 65: 352-358. http:// dx.doi.org/10.1016/j.enbuild.2013.06.007

Langston, C.; Shen, L. Y. 2007. Application of the adaptive reuse potential model in Hong Kong: a case study of Lui Seng Chun, International Journal of Strategic Property Management 11(4): 193-207. http://dx.doi.or g/10.1080/1648715X.2007.9637569

Langston, C.; Wong, F. K.; Hui, E.; Shen, L. Y. 2008. Strategic assessment of building adaptive reuse opportunities in Hong Kong, Building and Environment 43(10): 1709-1718. http://dx.doi.org/10.1016/j. buildenv.2007.10.017

Langston, C.; Yung, E. H. K.; Chan, E. H. W. 2013. The application of ARP modelling to adaptive reuse projects in Hong Kong, Habitat International 40: 233-243. http://dx.doi.org/10.1016/j.habitatint.2013.05.002

Lee, S. Y.; Brand, J. L. 2005. Effects of control over office workspace on perceptions of the work environment and work outcomes, Journal of Environmental Psychology 25(3): 323-333. http://dx.doi.org/10.1016/j. jenvp.2005.08.001

Latham, D. 2000. Creative re-use of buildings, vol. 1. UK, Shaftesbury: Donhead.

Ling, F. Y. Y.; Liu, M. 2004. Using neural network to predict performance of design-build projects in Singapore, Building and Environment 39(10): 1263-1274. http://dx.doi.org/10.1016/j.buildenv.2004.02.008

Lu, Y.; Shi, J. 2013. Investigation of the reuse of unused campus space, schools in Taiwan as examples, Scientific Journal of Architecture 3(1): 1-11.

Li, J.; Cheng, J. H.; Shi, J. Y.; Huang, F. 2012. Brief introduction of back propagation (BP) neural network algorithm and its improvement, in Jin, D.; Lin, S. (Eds.). Advances in computer science and information engineering. Berlin, Heidelberg: Springer, 553-558. http://dx.doi.org/10.1007/978-3-642-30223-7_87 
Liao, H. P. 2003. An assessment study on adaptive reuse of public deserted spaces. Master's thesis, Taichung, Republic of China: Chaoyang University of Technology.

Mine, T. Z. 2013. Adaptive re-use of monuments restoring religious buildings with different uses, Journal of Cultural Heritage 14(3): 14-19. http://dx.doi. org/10.1016/j.culher.2012.11.017

Ministry of Culture. 2011. Cultural Heritage Preservation Act [online]. Ministry of Culture, Republic of China. Available at: http://law.moc.gov.tw/law/ EngLaw Content.aspx?Type=E\&id=3 [accessed 28 January 2015]

Murtagh, W. J. 1988. Keeping time: the history and theory of preservation in America. Pittstown, NJ: Main Street Press.

National Policy Foundation (NPF). 2008. NPF research report: examination and evaluation of vacant space reuse policy [online]. National Policy Foundation, Republic of China. Available at: http://www.npf.org.tw/ post/2/4332 [accessed 31 January 2015]

Nyaupane, G. P.; Morais, D. B.; Dowler, L. 2006. The role of community involvement and number/type of visitors on tourism impacts: a controlled comparison of Annapurna, Nepal and Northwest Yunnan, China, Tourism Management 27(6): 1373-1385. http://dx.doi.org/10.1016/j.tourman.2005.12.013

Nelson, L. H. 2005. Architectural character: identifying the visual aspects of historic buildings as an aid to preserving their character [online]. Preservation Briefs, Department of the Interior, National Park Service, Washington DC. Available at: http://www.cr.nps. gov/hps/tps/briefs/brief17.htm [accessed 1 July 2012]

Oliver, C. 1997. Sustainable competitive advantage: combining institutional and resource-based views, Strategic Management Journal 18(9): 697-713. http://dx.doi.org/10.1002/(SICI)1097-0266

O’Neill, M. J. 1994. Work space adjustability, storage, and enclosure as predictors of employee reactions and performance, Environment and Behavior 26(4): 504526. http://dx.doi.org/10.1177/001391659402600403

Pelling, M.; High, C. 2005. Understanding adaptation: what can social capital offer assessments of adaptive capacity?, Global Environmental Change 15(4): 308319. http://dx.doi.org/10.1016/j.gloenvcha.2005.02.001

Rojas, R. 1996. Neural networks: a systematic introduction. Berlin, New-York: Springer-Verlag.

Prowler, D. 2008. Whole building design guide. National Institute of Building Sciences, USA.

Rabun, J. S. 2000. Structural analysis of historic buildings: restoration, preservation, and adaptive reuse applications for architects and engineers. New York: Wiley.

Roychansyah, M. S.; Ishizaka, K.; Omi, T. 2005. A study of the indicators for city compactness measurement: case study of 63 cities in Tohoku region in 1980-2000, Journal of Architecture and Planning (595): 107-115.

Russell, P.; Moffat, S. 2001. Adaptability of buildings. IEA Annex 31 Energy - Related Environmental Impact of Buildings.

Shipley, R.; Utz, S.; Parsons, M. 2006. Does adaptive reuse pay? A study of the business of building renovation in Ontario, Canada, International Journal of Heritage Studies 12(6); 505-520. http://dx.doi. org/10.1080/13527250600940181
SCCP. 2013a. The story of SCCP [online]. Songshan Cultural and Creative Park, Taipei. Available at: http:// www.songshanculturalpark.org/en/index.html [accessed 8 August 2014]

SCCP. 2013b. Mission [online]. Songshan Cultural and Creative Park, Taipei. Available at: http://www. songshanculturalpark.org/en/index.html [accessed 8 August 2014]

Stevenson, W. J.; Hojati, M. 2007. Operations management, vol. 8. Boston: McGraw-Hill/Irwin.

Stagl, S.; O'Hara, S. U. 2002. Motivating factors and barriers to sustainable consumer behaviour, International Journal of Agricultural Resources, Governance and Ecology 2(1): 75-88. http://dx.doi.org/10.1504/ IJARGE.2002.000023

Taipei Culture Foundation. Songshan cultural and creative park [online]. Taipei Culture Foundation, Taipei. Available at: http://www.taipeiculture.org/English/08.html [accessed 8 August 2014]

Trancik, R. 1986. Finding lost space: theories of urban design. New York: Wiley.

Tan, Y.; Shen, L. Y.; Langston, C. 2014. A fuzzy approach for adaptive reuse selection of industrial buildings in Hong Kong, International Journal of Strategic Property Management 18(1): 66-76. http:// dx.doi.org/10.3846/1648715X.2013.864718

United Nations Educational Scientific and Cultural Organization. 2007. Asia conserved: lessons learned from the UNESCO Asia-Pacific heritage awards for culture heritage conservation (2004-2004). United Nations Educational Scientific and Cultural Organization, Bangkok.

Vakili-Ardebili, A. 2007. Complexity of value creation in sustainable building design (SBD), Journal of Green Building 2(4): 171-181. http://dx.doi.org/10.3992/ jgb.2.4.171

Williams, C. C. 1996. Understanding the role of consumer services in local economic development: some evidence from the Fens, Environment and Planning $A$ 28(3): 555-571. http://dx.doi.org/10.1068/a280555

White, S. M.; McDaniel, J. B. 1999. The zoning and real estate implications of transit-oriented development, No. 12. National Research Council, Transportation Research Board.

Yang, H. S. 2013. Integrating government and non-governmental organizations for the protection of cultural property, Journal of Cultural Property Conservation, 23: 71-92 [online]. Available at: http://www.boch.gov. tw/boch/frontsite/cms/newsDetailViewAction.do?meth od=doViewNewsDetail\&contentId=5377\&isAddHitR ate $=$ true \&relation $\mathrm{Pk}=5377 \&$ tableName $=$ content\&isc ancel=true\&menuId=3507 [accessed 31 January 2015]

Yudelson, J. 2010. Greening existing buildings. New York: McGraw Hill.

Yung, E. H.; Chan, E. H. 2012. Implementation challenges to the adaptive reuse of heritage buildings: towards the goals of sustainable, low carbon cities, Habitat International 36(3): 352-361. http://dx.doi. org/10.1016/j.habitatint.2011.11.001

Zhang, Y. R.; Lin, Y. H. 2013. The impact of female wage on fertility in Taiwan: a wavelet analysis, Journal of Nan Kai 10(2): 53-63. 